\title{
CAUSALITY ANALYSIS OF DISAGGREGATED FDI INFLOWS ON SECTORIAL GROWTH IN OECD AREA
}

\author{
Lawrence Ogbeifun* \\ Department of Economics, University of Mississippi, USA \\ E-mail:logbeifu@go.olemiss.edu
}

\author{
Olatunji Abdul Shobande \\ Business School, University of Aberdeen, UK \\ E-mail: olatunji.shobande@abdn.ac.uk
}

(Received: July 2020: Accepted: August 2020; Published: October 2020)

\begin{abstract}
This article revisits the link between disaggregated Foreign Direct Investment (FDI) inflows and sectorial growth using the panel dataset of 25 Organisation for Economic Co-operation and Development (OECD) countries for the period 1990 to 2017. It adopted the panel fixed effect and Feasible Generalized Least Squares Approach in its analysis. The findings show that disaggregated FDI inflows have the potential to improve growth in the OECD area with adverse effects on domestic investment and inflationary pressure. Additionally, the results further indicate that disaggregated FDI inflows have a positive and significant relationship on the service and manufacturing sector but with no evidence shown on the agricultural industry. Thus, the study concludes that efficient reallocation of FDI resource(s) among sectors will not only boost output growth but also impact on the real economy. However, the necessary policy strategy to regulate this inflow is vital to mitigate its negative impact on domestic investment and inflation pressure.
\end{abstract}

Keywords: Foreign direct investment; growth; panel data; causal analysis; fixed effect; OECD

JEL Codes: F21, F35, F43

\section{Introduction}

The potential of FDI inflow as a viable instrument in promoting economic growth has enjoyed huge debates, research and investigation from mainstream economists with the intent to understand the intricacies of the paradigm (Solow, 1956; Ray, 1989; Acemoglu, 2009). Despite the volume of literature generated over the years,

*Corresponding author: Lawrence Ogbeifun. E-mail: logbeifu@go.olemiss.edu

Copyright $(\mathrm{C} 2020$ The Author(s). Published by VGWU Press

This is an Open Access article distributed under the terms of the Creative Commons BY 4.0 license (Creative Commons - Attribution 4.0 International - CC BY 4.0) which permits unrestricted use, distribution, and reproduction in any medium, provided the original author and source are credited. 
Ogbeifun, L., Shobande, O.A., (2020)

Causality Analysis of Disaggregated FDI Inflows on Sectorial Growth in OECD Area

there is yet a universally accepted stance and position in the face of inconsistencies reported as results of these studies and investigations (Kurtishi-Kastrati, 2013; Alam \& Shah, 2013). Thus, the need for further studies has been a necessity to understand further and explore the intricacies of the concept. Also, the inability of scholars to reach a consensus makes it difficult to pinpoint the rationale argument for promoting FDI initiatives. Thus, this article revisits the role of aggregated and disaggregated FDI inflows on aggregated growth among the OECD countries. It made a theoretical and empirical contribution to the use of external financing as a driver of sectorial growth among OECD countries.

FDI inflow has become a trend in the business world. Many developed economies are triggered to extend facilities and businesses in foreign countries with the hope of continuing their access to market and explore resources in those countries (Bengoa-Calvo \& Sanchez-Robles, 2003). FDI is often cited as a good prospect for investors for many reasons. First, FDI is often considered as the extended source of raw material for production and distribution of goods across regions of the world (Lim 1983; Kapuria, 2007). It, therefore, aids the export growth of home countries and extends production activities in different sectors in foreign countries. By intensifying production and consumption activities, foreign investors can capture a big market and make a massive profit from trade relations (Tsai, 1994; Leibrecht \& Scharler, 2009). Furthermore, the FDI inflow is used to break trade policies of host countries to enjoy lower economies of scale, by lowering cost and seeking incentives (Acemoglu, 2002; Alfaro, 2003; Alguacil et al., 2011). Today, the quest for FDI inflow has multiplied, with over 48 per cent of global FDI being controlled by OECD countries; thus, the organizaion is reputed to host the most substantial volume of FDI inflows in the world.

In 2017, the available report showed that FDI inflows fell by 53 per cent, but recorded a compensatory 23 per cent rise in 2018. By 2019, available records showed that OECD countries still attracted more than 12 per cent of the global FDI inflows. Thus, the changing trend in the FDI flows in OECD area needs to be reexamined. It is unclear whether or not FDI inflows account for the disparities in the growth trajectory of this region. Similarly, whether or not disaggregated, FDI inflow has a relative impact on the real economy equally deserves an urgent review.

Succinctly stated, this research is inspired to investigate OECD's FDI for the following reasons: First, disaggregated FDI inflows is a potential source of external financing for an economy experiencing a setback in domestic resource mobilization. Additionally, it serves as a further source of a financial resource through which an emerging economy can promote investment by fostering sectoral growth, which in turn supports sectoral development. Second, several studies (De Mello, 1999; Campos \& Kinoshita, 2002; Golub, 2003; Sohinger, 2005; Ghosh et al., 2012; 
Ogbeifun, L., Shobande, O.A., (2020)

Causality Analysis of Disaggregated FDI Inflows on Sectorial Growth in OECD Area

Pazienza, 2015), have suggested that disaggregated FDI inflows could help the fastgrowing economy to expand investment in the real economy, to meet the production of consumable goods needed to meet the demand of the teeming population. Third, understanding the broad consequence of over-dependence on disaggregated FDI inflows as a key driver of sectoral growth could help promote the importance and need to formulate policies that will attract further flow through government incentives. Fourth, it is widely recognized that gaining access to the global market may require synergy in trade policies, which provides long-run benefits in managerial expertise as well as job creation and can be achieved by promoting FDI inflows (Nicoletti \& Scarpetta, 2006; Koyama \& Golub, 2006).

Rather than pursuing the FDI-growth in previous studies, we built on existing literature, by re-examining the potential of disaggregated FDI inflows on disaggregated growth with a specific focus on OECD countries. We searched for the causality linkage between disaggregated FDI inflows and sectoral growth. Additionally, the study made at least five contributions to existing literature which includes: First, emerging market economy are confronted with an increasing quest for FDI inflows, which could have a devastating consequence on the market size and domestic assets. Second, the potential effects of FDI inflow on domestic investment are still unknown. Thus, it is unclear whether or not policymakers should be biased towards formulating policies that encourage trade openness. Third, the aftermath effect of overdose of FDI inflow on the consequence of inflationary pressure is still uncertain. Fourth, the potential impact of FDI inflow on sectorial decomposition and overall output level is still widely contested. Fifth, reconciling the suitable econometric approach in resolving the potential identification problem, which is often taken for granted in previous studies will not only provide more robust policy remedy towards explaining the link between FDI inflow and economic growth.

The study is organized as follows: In section two, we reviewed relevant literature. Next is section three describing the data and methodology, which includes model specification. Section four presents the results and the discussion, while section five concludes with policy recommendations.

\section{Literature Review}

FDI inflows are widely acknowledged as the primary channel through which countries suffering from resource gap meet their contractual obligation while enhancing economic growth. Although the research on the link between FDI and real economic variables are inconsistent and far from conclusion, various studies have shown that the potential of promoting economic growth through FDI may have differential impacts on domestic investment. In fact, some of these studies would argue that domestic firms are not favored by foreign capital flows due to the

94 Sciendo Studia Universitatis "Vasile Goldis" Arad. Economics Series Vol 30 Issue 4/2020 ISSN: 1584-2339; (online) ISSN: $2285-3065$

Web: publicatii.uvvg.ro/index.php/studiaeconomia. Pages $92-110$ 
Ogbeifun, L., Shobande, O.A., (2020)

Causality Analysis of Disaggregated FDI Inflows on Sectorial Growth in OECD Area

competition and risk of an investment that is likely to crowd out from such incentives. Others contend widely that consumption and capital flight are possible issues surrounding the use of foreign flow to stimulate investment. On the contrary, studies focusing on FDI inflows and sectoral growth remain inconclusive and still controversial. However, what can be deduced from previous studies is that the potential effect of FDI on sectoral development is unclear.

At the moment, two standard strands of literature are used in explaining the connection between FDI and economic growth. The first strand of research warns on the danger of relying on an external source of financing for growth. This approach further suggests that FDI does not promote local development and cannot ascertain sectorial progress (Hunya, 2002; Hsiao \& Shen, 2003; Alam \& Shah, 2013). Additionally, the hypothesis recognised the possibility of foreign investors to crowd out domestic investment. Similarly, the potential that foreign investors can overshadow the local economy and generate what could result in capital flight is critically underlined. The second strand suggests that one way to close the gap between saving and investment is by promoting external financing for growth (Ruane \& Gorg, 1997, Agiomirgianakis et al., 2003, Mukhopadhyay, 2006, Chakraborty \& Nunnenkamp, 2008, Agrawal \& Khan, 2011, Zekarias, 2016). The hypothesis claims that external funding through FDI will not only spur growth but bring about knowledge spill over (De Mello, 1997; Balasubramanyam et al., 1999; Antras \& Helpman, 2004). The contrasting view propelled by this hypothesis provoked a substantial volume of empirical research. It is interesting to note that contemporary research investigating the link between FDI and growth is not only highly controversial but also reported mixed and inconsistent results. For example, a study by Buchanan et al. (2012) and Rjoub et al. (2007) found positive evidence on the connection between FDI inflow and economic growth.

On the contrary, Balakrishman et al. (2013) investigated the drivers of FDI in the Middle East and North Africa (MENA) and reported that FDI limits potential growth among the countries examined. Similarly, Hayakawa et al. (2013) found no evidence connecting financial risk and FDI but indicated the possibility of its negative impacts. Comparably, Mahembe and Odhiambo (2014) examined the dynamics of FDI inflows and economic growth in six low-income SADC economies and reported that foreign competition harms the real economy of host countries. Danzman (2020) found an upsurge in financial restraints connected with a decrease in foreign equity constraints and concludes that domestic political institutions favor avenues for attracting FDI benefits.

Ghosh and Wang (2010) observed the role of FDI on economic growth in 24 developed countries and reported a positive effect of inward FDI on economic growth through research and development. Agiomirgianakis et al. (2003) examined a panel of 20 OECD countries for the period of 23 years covering 1975-1997, 
Ogbeifun, L., Shobande, O.A., (2020)

Causality Analysis of Disaggregated FDI Inflows on Sectorial Growth in OECD Area

reported that FDI has a positive and significant link with economic growth during the period reviewed.

Likewise, Bissinger (2012) examines the connection between Myanmar FDI inflows and economic growth and its impact on sectoral composition. He reported a negative relation based on poor regulation. Wang and Balasubramanyam (2011) investigated the link between FDI, aid, and economic growth in Vietnam and reported that FDI and aids potentially promoted sustainable growth during the period reviewed. Zang and Baimbridge (2014) assessed the link between FDI and economic growth in OECD countries and reported no causality in five countries but with reverse causality in four countries.

Using a panel of 15 EU countries for the period 1998-2008, Ozkan-Gunay (2011) identified the key rationale for FDI among the EU countries. This influenced economic and technological advancement and reported that differential macroeconomic factors such as inflation and unemployment explained the potential of FDI among the countries examined. Similar findings by Galego et al. (2004) also recognized that FDI has the potential to boost economic growth among EU countries beyond limits. Inversely, Athukorala and Wagle (2011) assessed the determinants of FDI in Malaysia in comparison Southeast Asia standpoint and reported that FDI crowd out domestic investment in Malaysia.

Hoang et al. (2010) investigate the impact of FDI on economic growth using a panel dataset for sixty-one provinces in Vietnam for the period 1995-2006 and reported that FDI could not translate to economic growth due to low access to technology, human capital and trade constraint. Rios-Morales (2016) considered the potential of Chinese FDI in Switzerland and reported that resource capabilities and different motivations made it difficult for Switzerland firms to compete with Chinese firms.

Wooster and Diebel (2010) reviewed the potential of FDI spillover in developing countries using 32 studies collected based on relevance and bias for FDI spillover and reported a positive effect of FDI on Asian countries. Yi et al. (2015) investigated the potential of region-specific FDI spillover effect among domestic firms in China and reported mixed evidence on their benefits. Lenaerts and Merlevede (2015) researched firms' productivity spillover of FDI in Romania and reported that large firms are less embedded in the domestic economy as this has a negative effect on small and medium domestic firms. Chen (2015) examines the dense concentration of FDI China Coastal region and their potential to promote economic growth. The scholar tested different Chinese province's level data for inter-regional knowledge spillover on FDI and reported that trade policies ensure that FDI potential is realised.

Some studies focused on the connection between Total factor Productivity (TFP) and FDI inflows and documented a positive result. For example, using a Granger

96 Sciendo Studia Universitatis "Vasile Goldis" Arad. Economics Series Vol 30 Issue 4/2020 ISSN: 1584-2339; (online) ISSN: $2285-3065$

Web: publicatii.uvvg.ro/index.php/studiaeconomia. Pages $92-110$ 
Ogbeifun, L., Shobande, O.A., (2020)

Causality Analysis of Disaggregated FDI Inflows on Sectorial Growth in OECD Area

causality approach, Zhang (2002) investigated the FDI inflows and production efficiency using cross-region regression analysis in 19 regions and reported a bidirectional flow between FDI and TFP in the regions. Similar studies by Sadik and Bolbol (2001) examined the causality between FDI and TFP in Egypt, Oman, Saudi Arabia and Tunisia, and reported a positive relationship among the variables used. Combining the correlation and regression, Bano and Tabbada (2015) investigated the determinants foreign direct investment outflows for the period 1980-2011 and reported that high level of economic growth, large foreign reserves and saving potential are related to sources of FDI inflows among the countries examined during the period reviewed. Following a cointegration approach, Masron and Shahbudin (2010) observed the determinants of FDI on economic growth in Malaysia and Thailand and reported that competition, domestic market and capital market structure are the key drivers of FDI during the period.

Several studies have shown that FDI can have both positive and negative macroeconomic impacts in transition economies. For example, Ayyagari and Kosova (2010) reported that FDI inflow may have a negative impact on domestic firms in the Czech Republic. On the contrary, Blonigen and Piger (2014) examined the effect of bilateral FDI on a variety of endowments and trade agreements using the Bayesian Model Averaging and reported that host incentive and trade factors are crucial for successive FDI on economic growth. Iwasaki and Tokunaga (2014) re-examined the potential of FDI on economic growth in Central and Eastern Europe and the former Soviet Union and reported genuine evidence of a zero nonFDI effect among the countries investigated.

Contrariwise, most of the regional studies on the potential of spillovers from FDI record positive findings. For example, a study by Madariaga and Poncet (2007) utilized a city-level data for regional spillover and reported that FDI inflows affect economic growth in nearby cities examined. Ouyang and Fu (2012) estimated FDI using city-level data for the period 1996-2004 and reported that FDI has positive spillovers on regional economic growth. On the contrary, Wang et al. (2017) estimated the potential FDI inflow using the provincial industry-level data between 1990-2005 and reported a negative between FDI spillovers and economic growth at inter-regional. Using a sectoral decomposition approach, Ali and Asgher (2016) investigated the potential of FDI on economic growth for China, Pakistan, India, Bangladesh, and Sri Lanka for the period 2000-2015. The authors utilised a Robust Standard Error Model and reported a substantial positive and significant effect of manufacturing FDI on economic growth with a minor effect from the agricultural sector, while inconclusive evidence was reported for the service sector. Nasir et al. (2016) investigated the Granger causality between FDI and economic growth in BRICS countries for the period 1992-2013 and reported a unidirectional flow from FDI to economic growth among the panel of BRICS countries examined. 
Ogbeifun, L., Shobande, O.A., (2020)

Causality Analysis of Disaggregated FDI Inflows on Sectorial Growth in OECD Area

Based on the review above, it appears there is no consensus reached on the relationship between FDI and economic growth. As it were, little evidence is available on the potential of FDI inflows to promote economic growth with large disagreement on the differential effect on domestic investment and consumption. Similarly, the linkage between FDI and sectoral growth is less in research with few ones recording inconsistent results. Thus, the existing lacuna in the present literature calls for further research, which is motivated by this present one. Hence, the present study is timely as it will uncover the rationale for promoting FDI in OECD countries as it affects sectoral growth.

\section{Data and Methodology}

\subsection{Data}

Data for this study are pooled from various sources due to difficulty in getting most cross-sections of developing countries. Growth in this study is measured as the overall wellbeing of the citizenry (called the aggregated growth) and sectoral growth (called the disaggregated growth. By disaggregated growth, we look at growth in the primary sector - agriculture, secondary sector - industry and manufacturing, and tertiary sector - service). Using data from the World Bank's World Development Indicators (WDI) (2019), the aggregated growth was measured as the growth of real per capita GDP (PCGG) in current US dollars, while the disaggregated growth consists of manufacturing value added (GDP_MAN), service value added (GDP_SERV), industrial value-added (GDP_IND), and agricultural value-added (GDP_AGR)-all as a percentage of GDP.

Macroeconomic stability variable, proxy by inflation and measured as the percentage of change in the GDP deflator, was from the WDI (2019). Trade openness was proxied by the average of the sums of exports plus imports to GDP; Government consumption expenditure, from WDI (2019), is the ratio of central government expenditure to GDP; and gross fixed capital formation proxy investment.

Detailed information on aggregate FDI is available in the United Nations Conference on Trade and Development (UNCTAD) while FDI by sectors is from OECD's International Direct Investment Statistics Yearbook (2019), which are available, in most cases, ranging from 1990-2003. In the estimation of aggregated FDI on aggregated and sectoral growth, the scope covers 25 countries spanning from 1990 to 2017: Chile, Hungary, Mexico, Poland, South Korea, Turkey, Argentina, Bangladesh, Brazil, Bulgaria, China, Columbia, Egypt, India, Indonesia, Malaysia, Nigeria, Peru, Philippines, Romania, Russia, South Africa, Thailand, Ukraine, and Venezuela. On the other hand, due to the limitation of data for

98 Sciendo Studia Universitatis "Vasile Goldis" Arad. Economics Series Vol 30 Issue 4/2020 ISSN: 1584-2339; (online) ISSN: $2285-3065$

Web: publicatii.uvvg.ro/index.php/studiaeconomia. Pages $92-110$ 
Ogbeifun, L., Shobande, O.A., (2020)

Causality Analysis of Disaggregated FDI Inflows on Sectorial Growth in OECD Area

disaggregated FDI across OECD countries, our analysis of disaggregated FDI on aggregated growth cover six countries (Chile, Hungary, South Korea, Mexico, Poland, and Turkey) spanning from 1990 to 2013.

\section{Research Questions}

In light of the above, this study seeks to address the following questions:

a) Does cumulative FDI inflow have impact on aggregated growth in the OECD area?

b) Does cumulative FDI inflow explain the disparities in disaggregated growth in the OECD area?

c) What impact does disaggregated FDI inflows have on aggregated growth in the OECD area?

The answers to these questions will not only provide further explanation on the rationale for the attractiveness of FDI inflows in OECD areas but also contribute strategy towards increasing or decreasing the dominance of foreign investors in the region.

\subsection{Model Specification}

In line with the theoretical framework, the empirical specification to establish the relationship between capital flows and economic growth is:

$$
Y_{i, t}=\alpha_{0}+\alpha_{1} K_{i, t}+\beta Z_{i, t}+\xi_{i, t}
$$

Where $\mathrm{Y}_{i, t}$ denotes economic growth; $K_{i, t}$ represents the capital flow component-foreign direct investment (FDI) inflows; $Z_{i, t}$ is a vector of controlled variables which includes: gross fixed capital formation (GFCF), government consumption expenditure (GCE), inflation (INF), and trade openness (TO).

Taking equation (1) to the data in a standard panel approach restricts all the slopes to the same for each cross-section unit, while only intercepts, modelled as fixed or random, are allowed to vary. The error term is:

$$
\xi_{i, t}=\gamma_{i}+\lambda_{t}+\epsilon_{i, t}
$$

Where $\gamma_{i}$ are fixed effects controlling for time-invariant shocks to growth which allows for variation across country-sector and $\lambda_{t}$ are time dummies.

As a benchmark, we estimate the impact of aggregated FDI inflows on aggregated growth as well as the impact of disaggregated FDI on aggregated growth, respectively as follows: 
Ogbeifun, L., Shobande, O.A., (2020)

Causality Analysis of Disaggregated FDI Inflows on Sectorial Growth in OECD Area

$$
\begin{gathered}
\text { Growt }_{i, t}=\alpha_{0}+\alpha_{1} \mathrm{FDI}_{\mathrm{i}, \mathrm{t}}+\beta_{1} \mathrm{TO} O_{i, t}+\beta_{2} \mathrm{GCE} E_{i, t}+\beta_{3} \mathrm{GCF} C_{i, t}+\beta_{4} \mathrm{INF} F_{i, t}+\xi_{i, t} \\
\text { Growt }_{i, t}=\alpha_{0}+\sum_{k=1}^{8} \alpha_{1, k} \mathrm{IFDI}_{i, \mathrm{t}}^{\mathrm{k}}+\beta_{1} \mathrm{~T} O_{i, t}+\beta_{2} \mathrm{GC} E_{i, t}+\beta_{3} \mathrm{GCF} C_{i, t}+\beta_{4} \mathrm{IN} F_{i, t}+\xi_{i, t}
\end{gathered}
$$

Where $\operatorname{lFD} I_{i, t}^{k}$ is the log of FDI inflow in the $k$ corresponding sector: primary (FDIPRIM); agriculture and fishing (FDIAF); manufacturing (FDIMAN); total service (FDITS); energy, gas and water (FDIEGW); financial intermediation (FDIFIN); mining and quarry (FDIMQ); and construction (FDICON).

In order to examine the impact of aggregated FDI on disaggregated growth, the following equations will be estimated as follows:

$$
\text { Growt }_{i, t}^{j}=\alpha_{0}+\alpha_{1} \mathrm{FDI}_{i, t}+\beta_{1} \mathrm{TO}_{i, t}+\beta_{2} \mathrm{GCE} E_{i, t}+\beta_{3} \mathrm{GCF} C_{i, t}+\beta_{4} \mathrm{IN} F_{i, t}+\xi_{i, t}
$$

Where $\mathrm{j}$ corresponds to the agricultural, industrial, manufacturing and service value added to GDP respectively.

\section{Empirical Results}

This section presents the estimated results and discussion of findings. It begins with the descriptive statistics, correlation matrix, and estimated results.

\subsection{Descriptive statistics}

Table (1) report descriptive statistics describing the qualities of data utilized with corresponding mean and standard deviations. The average value and related deviation of the per capita GDP (PCGG) stood at 2.6 (4.3), while for the foreign direct investment (FDI) 2.5 (2.6), trade openness (TO) 63.5 (37.5), gross fixed capital formation (GFCF) 23.5 (6.6), government consumption expenditure (GCE) 13.4 (4.6), and inflation (INF) 53.3 (336) amongst others.

Table 1 Summary statistics of the variables considered in model

\begin{tabular}{lll}
\hline Variables & Mean & Standard deviation \\
\hline FDI & 2.580 & 2.609 \\
TO & 63.564 & 37.569 \\
GCE & 13.477 & 4.683 \\
GFCF & 23.551 & 6.693 \\
INF & 53.188 & 336.201 \\
PCGG & 2.673 & 4.341 \\
GDP_SERV & 50.732 & 6.775 \\
GDP_MAN & 18.557 & 5.593 \\
GDP_IND & 32.551 & 7.189 \\
GDP_AGR & 10.111 & 6.669 \\
\hline
\end{tabular}


Ogbeifun, L., Shobande, O.A., (2020)

Causality Analysis of Disaggregated FDI Inflows on Sectorial Growth in OECD Area

\subsection{Correlation matrix}

Table 2 Correlation matrix between selected variables of the study

\begin{tabular}{|c|c|c|c|c|c|c|c|c|c|c|}
\hline Variables & FDI & TO & GCE & GFCF & INF & PCGG & $\begin{array}{l}\text { GDP } \\
\text { SERV }\end{array}$ & $\begin{array}{l}\text { GDP } \\
\text { MAN }\end{array}$ & $\begin{array}{l}\text { GDP } \\
\text { IND }\end{array}$ & $\begin{array}{l}\text { GDP } \\
\text { AGR }\end{array}$ \\
\hline FDI & 1.00 & & & & & & & & & \\
\hline TO & 0.26 & 1.00 & & & & & & & & \\
\hline GCE & 0.19 & 0.27 & 1.00 & & & & & & & \\
\hline GFCF & 0.08 & 0.13 & -0.28 & 1.00 & & & & & & \\
\hline INF & -0.10 & -0.12 & 0.05 & -0.06 & 1.00 & & & & & \\
\hline PCGG & 0.17 & 0.05 & -0.15 & 0.34 & -0.23 & 1.00 & & & & \\
\hline GDP_SERV & 0.13 & 0.01 & 0.38 & -0.32 & -0.16 & -0.08 & 1.00 & & & \\
\hline GDP_MAN & -0.14 & 0.40 & -0.06 & 0.45 & 0.17 & 0.06 & -0.36 & 1.00 & & \\
\hline GDP_IND & -0.03 & 0.27 & -0.24 & 0.35 & 0.09 & 0.07 & -0.60 & 0.63 & 1.00 & \\
\hline GDP_AGR & -0.22 & -0.19 & -0.59 & 0.18 & 0.06 & 0.03 & -0.58 & 0.06 & $-0,04$ & 1.00 \\
\hline
\end{tabular}

Table (2) presents the correlation matrix between selected variables and shows that: (i) trade openness (TO) and gross fixed capital formation (GFCF) are positively correlated to per capita GDP growth (PCGG) whereas government consumption expenditure (GCE) and inflation (INF) are negatively correlated with to PCGG; and (ii) FDI inflows is positively correlated to PCGG.

\subsection{Regression results}

Table 3 Results of aggregated FDI on aggregated growth

\begin{tabular}{|c|c|c|c|c|}
\hline \multicolumn{5}{|c|}{ Dependent variable: Aggregated growth } \\
\hline & Fixed Effect (1) & FGLS (2) & Fixed Effect (3) & FGLS (4) \\
\hline \multirow[t]{2}{*}{ FDI } & $0.3695 * * *$ & $0.2648 * * *$ & $0.2294 * * *$ & $0.1322 * *$ \\
\hline & $(0.0671)$ & $(0.0535)$ & $(0.0675)$ & $(0.0604)$ \\
\hline \multirow[t]{2}{*}{ TO } & $0.0198 * *$ & -0.0034 & -0.0109 & -0.0160 \\
\hline & $(0.0894)$ & $(0.0049)$ & $(0.0098)$ & $(0.0099)$ \\
\hline \multirow[t]{2}{*}{ GCE } & $-0.4689 * * *$ & $-0.1540 * * *$ & $-0.5049 * * *$ & $-0.4768 * * *$ \\
\hline & $(0.0798)$ & $(0.0281)$ & $(0.0796)$ & $(0.0814)$ \\
\hline \multirow[t]{2}{*}{ GFCF } & $0.0775 * *$ & $0.2412 * * *$ & $0.1165^{* * *}$ & $0.1922 * * *$ \\
\hline & $(0.0322)$ & $(0.0215)$ & $(0.0310)$ & $(0.0324)$ \\
\hline \multirow[t]{2}{*}{ INF } & $-0.0027 * * *$ & $-0.0014 * * *$ & $-0.0025^{* * *}$ & $-0.0015^{* * *}$ \\
\hline & $(0.0005)$ & $(0.0004)$ & $(0.0004)$ & $(0.0003)$ \\
\hline \multirow[t]{2}{*}{ Constant } & $5.0985 * * *$ & $-1.1339^{*}$ & $5.2686^{* * *}$ & $3.2004^{*}$ \\
\hline & $(1.5567)$ & $(0.6024)$ & (1.679) & (1.8042) \\
\hline $\mathrm{R}^{2}$ & 0.1604 & & 0.3109 & \\
\hline Hausman & 0.0000 & & 0.0000 & \\
\hline Country FE & No & No & Yes & Yes \\
\hline Time FE & No & No & Yes & Yes \\
\hline Region FE & No & No & Yes & Yes \\
\hline Observation & 700 & 700 & 700 & 700 \\
\hline Number of country & 25 & 25 & 25 & 25 \\
\hline \multicolumn{5}{|l|}{ Diagnostic Test } \\
\hline B-P LM & 0.0000 & & 0.0000 & \\
\hline CD test & 0.0000 & & 0.0000 & \\
\hline M-Wald test & 0.0000 & & 0.0000 & \\
\hline Type of autocorrelat & & Common & & Common \\
\hline
\end{tabular}

Notes: Modified Wald (M.Wald) test for groupwise heteroskedasticity; B-P LM test of independence; CD test is the p-value of the Pesaran (2015) test for cross-section dependence in the residuals. Wooldridge test for autocorrelation.

$*, * *, * * *$ denote $10 \%, 5 \%$, and $1 \%$ significance levels, respectively. Figures in brackets represents z-statistics. 
Table (3) presents the results of regressions performed with all the countries during the period from 1990 to 2017. The dependent variable across all columns is the aggregated growth-proxy by per capita GDP growth. Columns (1) and (2) present the results of the analysis performed without time dummy. The choice for the fixed effect model over the random effect model is justified by the Hausman test results. The diagnostic test suggests the problem of cross-section dependence and heteroscedasticity. To correct these problems, Wiggins and Poi (2001) suggest the feasible GLS (FGLS) hence, we mainly focus on the results from FGLS. In column (2), the coefficient of aggregated FDI is statistically significant and positively related to the aggregated growth in OECD countries. This means that increasing the amount of FDI that goes into OECD countries by say $1 \%$ will bring about a 26\% increase in aggregated growth in the bloc. This result is well above those found by Ghosh and Wang (2010) and Turkcan and Yetkiner (2010) who found FDI to have impact growth by about $10 \%$ and $1 \%$ respectively. Most of the controlled variables are statistically significant and negatively related to aggregated growth except for trade openness (TO) that is insignificant and GFCF that impact growth positively.

In columns (3) and (4), we re-estimate the model from the previous columns with the inclusion of time dummy, country dummy, and region dummy. The results do not differ in terms of the sign and significance of the coefficients but differ in magnitude. In column (4), an increase in aggregated FDI by say $1 \%$ will increase aggregated growth by about $13 \%$.

In Table (4), we present the results of a regression performed in each sector. We focused on the FGLS results for interpretation. All columns include time dummy, country dummy, and region dummy. Concerning the impact of aggregated FDI across the various sectors we considered, the analyses show significant results for aggregated FDI, which have a positive effect on service, industrial, and manufacturing industry. In terms of magnitude, increasing aggregated FDI by say $1 \%$ results in about $1.3 \%, 1.1 \%$, and $1.6 \%$ increase in the value-added to GDP growth contributed by the service, industrial and manufacturing sectors respectively. This result differs from those found by Vu and Noy (2009) who found aggregated FDI to have a negative and significant impact on these sectors for developed countries. On the contrary, the coefficient of aggregated FDI on the value-added to GDP contributed by the agriculture sector is negative and statistically insignificant. These results show that while aggregated FDI might have a significant impact on the aggregated GDP growth, its contribution to the different sectors that contribute to the GDP growth differ in sign and magnitude.

102 Sciendo Studia Universitatis "Vasile Goldis" Arad. Economics Series Vol 30 Issue 4/2020 ISSN: 1584-2339; (online) ISSN: $2285-3065$

Web: publicatii.uvvg.ro/index.php/studiaeconomia. Pages $92-110$ 
Ogbeifun, L., Shobande, O.A., (2020)

Causality Analysis of Disaggregated FDI Inflows on Sectorial Growth in OECD Area

\begin{tabular}{|c|c|c|c|c|c|c|c|c|}
\hline \multicolumn{9}{|c|}{ Table 4 Results of aggregated FDI on disaggregated growth } \\
\hline & \multicolumn{2}{|c|}{$\begin{array}{l}\text { Service sector } \\
\text { contribution to GDP } \\
\text { (GDP_SERV) }\end{array}$} & \multicolumn{2}{|c|}{$\begin{array}{l}\text { Industrial sector } \\
\text { contribution to GDP } \\
\text { (GDP_IND) }\end{array}$} & \multicolumn{2}{|c|}{$\begin{array}{l}\text { Agrico sector } \\
\text { contribution to GDP } \\
\text { (GDP_AGR) }\end{array}$} & \multicolumn{2}{|c|}{$\begin{array}{l}\text { Manufacturing sector } \\
\text { contribution to GDP } \\
\text { (GDP_MAN) }\end{array}$} \\
\hline & $\begin{array}{l}\text { FE } \\
\text { (1) }\end{array}$ & $\begin{array}{l}\text { FGLS } \\
(2)\end{array}$ & $\begin{array}{l}\text { FE } \\
\text { (3) }\end{array}$ & $\begin{array}{l}\text { FGLS } \\
\text { (4) }\end{array}$ & $\begin{array}{l}\text { FE } \\
(5)\end{array}$ & $\begin{array}{l}\text { FGLS } \\
(6)\end{array}$ & $\begin{array}{l}\text { FE } \\
\text { (7) }\end{array}$ & $\begin{array}{l}\text { FGLS } \\
(8)\end{array}$ \\
\hline FDI & $\begin{array}{l}0.2188^{* * * *} \\
(0.0742)\end{array}$ & $\begin{array}{l}0.0128^{* *} \\
(0.0042)\end{array}$ & $\begin{array}{l}0.2230^{* * * *} \\
(0.0652)\end{array}$ & $\begin{array}{l}0.0110^{* * *} \\
(0.0003)\end{array}$ & $\begin{array}{l}-0.0194 \\
(0.0443)\end{array}$ & $\begin{array}{l}-0.0057 \\
(0.0174)\end{array}$ & $\begin{array}{l}0.1347 * * \\
(0.0468)\end{array}$ & $\begin{array}{l}0.0164 \\
0.0006)\end{array}$ \\
\hline TO & $\begin{array}{l}-0.0337 * * * * \\
(0.0114)\end{array}$ & $\begin{array}{l}-0.0193 * * \\
(0.0084)\end{array}$ & $\begin{array}{l}0.0369 * * * \\
(0.0100)\end{array}$ & $\begin{array}{l}0.0266 * * * \\
(0.0781)\end{array}$ & $\begin{array}{l}-0.0013 \\
(0.0068)\end{array}$ & $\begin{array}{l}-0.0017 \\
(0.0048)\end{array}$ & $\begin{array}{l}0.0492 * * * \\
(0.0073)\end{array}$ & $\begin{array}{l}0.0343 * * * \\
(0.0055)\end{array}$ \\
\hline GCE & $\begin{array}{l}-0.2486^{* * * *} \\
(0.0920)\end{array}$ & $\begin{array}{l}0.3075^{\text {***** }} \\
(0.0735)\end{array}$ & $\begin{array}{l}-0.0700 \\
(0.0809)\end{array}$ & $\begin{array}{l}-0.2950 * * * \\
(0.0610)\end{array}$ & $\begin{array}{l}0.2050^{* * * * *} \\
(0.0550)\end{array}$ & $\begin{array}{l}0.0478 \\
(0.0415)\end{array}$ & $\begin{array}{l}-0.0257 \\
(0.0585)\end{array}$ & $\begin{array}{l}-0.2641^{* * *} \\
(0.0409)\end{array}$ \\
\hline GFCF & $\begin{array}{l}0.0723^{* * *} \\
(0.0360)\end{array}$ & $\begin{array}{l}0.0327 \\
(0.0291)\end{array}$ & $\begin{array}{l}0.1425 * * * \\
(0.0303)\end{array}$ & $\begin{array}{l}0.0408 \\
(0.0261)\end{array}$ & $\begin{array}{l}0.1621 * * * \\
(0.0206)\end{array}$ & $\begin{array}{l}0.0704 * * * \\
(0.0173)\end{array}$ & $\begin{array}{l}0.0874 * * * * \\
(0.0220)\end{array}$ & $\begin{array}{l}0.0129 \\
(0.0178)\end{array}$ \\
\hline INF & $\begin{array}{l}-0.0029^{* * * *} \\
(0.0007)\end{array}$ & $\begin{array}{l}-0.0013^{\text {*** }} \\
(0.0005)\end{array}$ & $\begin{array}{l}0.0043^{* * * *} \\
(0.0006)\end{array}$ & $\begin{array}{l}0.0018 * * * \\
(0.0004)\end{array}$ & $\begin{array}{l}0.0006 \\
(0.0004)\end{array}$ & $\begin{array}{l}0.0004 * * \\
(0.0002)\end{array}$ & $\begin{array}{l}0.0049^{* * * *} \\
(0.0004)\end{array}$ & $\begin{array}{l}0.0015^{* * * *} \\
(0.0003)\end{array}$ \\
\hline Constant & $\begin{array}{l}50.50 * * * \\
(1.865)\end{array}$ & $\begin{array}{l}47.66 * * * \\
(2.1179)\end{array}$ & $\begin{array}{l}31.21^{* * *} \\
(1.6176)\end{array}$ & $\begin{array}{l}30.70 * * * \\
(1.2434)\end{array}$ & $\begin{array}{l}17.19^{* * *} \\
(1.0996)\end{array}$ & $\begin{array}{l}11.18^{* * *} \\
(1.1453)\end{array}$ & $\begin{array}{l}15.16^{* * * *} \\
(1.1671)\end{array}$ & $\begin{array}{l}21.79 * * * \\
(0.9341)\end{array}$ \\
\hline $\mathrm{R}^{2}$ & 0.3749 & & 0.2918 & & 0.5627 & & 0.4428 & \\
\hline Hausman & 0.0000 & & 0.0000 & & 0.0000 & & 0.0000 & \\
\hline Country FE & Yes & Yes & Yes & Yes & Yes & Yes & Yes & Yes \\
\hline Time FE & Yes & Yes & Yes & Yes & Yes & Yes & Yes & Yes \\
\hline Region FE & Yes & Yes & Yes & Yes & Yes & Yes & Yes & Yes \\
\hline Observation & 686 & 651 & 686 & 651 & 686 & 651 & 686 & 651 \\
\hline $\begin{array}{l}\text { Number of } \\
\text { country } \\
\text { Diagnostic } \\
\text { Test }\end{array}$ & 25 & 25 & 25 & 25 & 25 & 25 & 25 & 25 \\
\hline B-P LM & 0.0000 & & 0.0000 & & 0.0000 & & 0.0000 & \\
\hline CD test & 0.0000 & & 0.0000 & & 0.0000 & & 0.0000 & \\
\hline M-Wald test & 0.0000 & & 0.0000 & & 0.0000 & & 0.0000 & \\
\hline $\begin{array}{l}\text { Type of } \\
\text { autocorrelatio }\end{array}$ & & Common & & Common & & Common & & Common \\
\hline
\end{tabular}

Notes: Modified Wald (M.Wald) test for groupwise heteroskedasticity; B-P LM test of independence; CD test is the p-value of the Pesaran (2015) test for cross section dependence in the residuals. Wooldridge test for autocorrelation.

$*, * *, * * *$ denote $10 \%, 5 \%$, and $1 \%$ significance levels, respectively. Figures in brackets represents z-statistics.

Pertaining to the controlled variables across all columns, most of the variables are negative and statistically significant. In most cases, the inclusion of the control variables improves the result of the R-square.

Table (5) shows the results of the FGLS for disaggregated effects of FDI on aggregated growth, with the country and time dummies. Column (1) presents the specification with only the control variables, excluding the primary variables of interest. We then add the disaggregated FDI in the subsequent columns. Results in columns (2) through (9) show that coefficients of most disaggregated FDI are nonsignificant, while those that are significant have a negative impact on aggregated growth. There are various possible reasons for the failure of FDI to contribute to aggregate economic growth. First, a large share of FDI among OECD countries ends up in countries where the quality of an institution is lower, as this will enable foreign investors to operate directly instead of bargaining with the local market and legal arrangements (Hausmann and Fernandez-Arias, 2000). 
Ogbeifun, L., Shobande, O.A., (2020)

Causality Analysis of Disaggregated FDI Inflows on Sectorial Growth in OECD Area

\begin{tabular}{|c|c|c|c|c|c|c|c|c|c|}
\hline \multicolumn{10}{|c|}{ Table 5 FGLS: Results of disaggregated FDI on aggregated growth } \\
\hline \multicolumn{10}{|c|}{ Dependent variable: Aggregated growth } \\
\hline & (1) & (2) & (3) & (4) & (5) & (6) & (7) & (8) & (9) \\
\hline TO & $\begin{array}{l}0.01 \\
(0.01)\end{array}$ & $\begin{array}{l}-0.04 * * \\
(0.02)\end{array}$ & $\begin{array}{l}- \\
0.04 * * \\
(0.02)\end{array}$ & $\begin{array}{l}-0.04 * * \\
(0.02)\end{array}$ & $\begin{array}{l}-0.04^{* *} \\
(0.02)\end{array}$ & $\begin{array}{l}-0.04^{* *} \\
(0.02)\end{array}$ & $\begin{array}{l}-0.04 * * \\
(0.02)\end{array}$ & $\begin{array}{l}-0.04^{* *} \\
(0.02)\end{array}$ & $\begin{array}{l}- \\
0.04 * * \\
(0.02)\end{array}$ \\
\hline GCE & $\begin{array}{l}-0.17 \text { ** } \\
(0.08)\end{array}$ & $\begin{array}{l}0.29 * * \\
(0.11)\end{array}$ & $\begin{array}{l}0.26 * * \\
(0.13)\end{array}$ & $\begin{array}{l}0.27 * * \\
(0.12)\end{array}$ & $\begin{array}{l}0.29 * \\
(0.16)\end{array}$ & $\begin{array}{l}0.25^{* *} \\
(0.11)\end{array}$ & $\begin{array}{l}0.26^{* *} \\
(0.12)\end{array}$ & $\begin{array}{l}0.27 * * \\
(0.12)\end{array}$ & $\begin{array}{l}0.28^{* * *} \\
(0.11)\end{array}$ \\
\hline GFCF & $\begin{array}{l}0.22 * * \\
(0.06)\end{array}$ & $\begin{array}{l}0.19 * * \\
(0.09)\end{array}$ & $\begin{array}{l}0.26 * * \\
(0.08)\end{array}$ & $\begin{array}{l}0.26 * * \\
(0.07)\end{array}$ & $\begin{array}{l}0.30^{*} \\
(0.08)\end{array}$ & $\begin{array}{l}0.27 * * \\
(0.07)\end{array}$ & $\begin{array}{l}0.30^{* *} \\
(0.10)\end{array}$ & $\begin{array}{l}0.25^{* *} \\
(0.08)\end{array}$ & $\begin{array}{l}0.25^{* *} \\
(0.07)\end{array}$ \\
\hline INF & $\begin{array}{l}-0.02 \\
(0.01)\end{array}$ & $\begin{array}{l}-0.002 \\
(0.04)\end{array}$ & $\begin{array}{l}-0.02 \\
(0.02)\end{array}$ & $\begin{array}{l}-0.02 \\
(0.02)\end{array}$ & $\begin{array}{l}-0.01 \\
(0.02)\end{array}$ & $\begin{array}{l}-0.01 \\
(0.04)\end{array}$ & $\begin{array}{l}-0.01 \\
(0.06)\end{array}$ & $\begin{array}{l}-0.02 \\
(0.02)\end{array}$ & $\begin{array}{l}-0.03 \\
(0.02)\end{array}$ \\
\hline IFDIAF & & $\begin{array}{l}-0.41^{* *} \\
(0.04)\end{array}$ & & & & & & & \\
\hline IFDIPRIM & & & $\begin{array}{l}-0.05 \\
(0.18)\end{array}$ & & & & & & \\
\hline IFDIFIN & & & & $\begin{array}{l}-0.02 \\
(0.26)\end{array}$ & & & & & \\
\hline IFDITS & & & & & $\begin{array}{l}-0.08 \\
(0.41)\end{array}$ & & & & \\
\hline IFDICON & & & & & & $\begin{array}{l}-0.10 \\
(0.20)\end{array}$ & & & \\
\hline IFDIEGW & & & & & & & $\begin{array}{l}-0.12 \\
(0.23)\end{array}$ & & \\
\hline IFDIMQ & & & & & & & & $\begin{array}{l}-0.06 \\
(0.16)\end{array}$ & \\
\hline IFDIMAN & & & & & & & & & $\begin{array}{l}- \\
0.27 * * \\
(0.07)\end{array}$ \\
\hline Constant & $\begin{array}{l}-0.42 \\
(1.88)\end{array}$ & $\begin{array}{l}-1.43 \\
(3.35)\end{array}$ & $\begin{array}{l}-3.49 \\
(3.20)\end{array}$ & $\begin{array}{l}-3.59 \\
(3.66)\end{array}$ & $\begin{array}{l}-5.14 \\
(5.67)\end{array}$ & $\begin{array}{l}-3.54 \\
(3.02)\end{array}$ & $\begin{array}{l}-4.31 \\
(3.70)\end{array}$ & $\begin{array}{l}-3.24 \\
(3.05)\end{array}$ & $\begin{array}{l}-3.54 \\
(3.02)\end{array}$ \\
\hline Country FE & Yes & Yes & Yes & Yes & Yes & Yes & Yes & Yes & Yes \\
\hline Time FE & Yes & Yes & Yes & Yes & Yes & Yes & Yes & Yes & Yes \\
\hline Observation & 168 & 168 & 168 & 168 & 168 & 168 & 168 & 168 & 168 \\
\hline $\begin{array}{l}\text { Number of } \\
\text { countries }\end{array}$ & 6 & 6 & 6 & 6 & 6 & 6 & 6 & 6 & 6 \\
\hline
\end{tabular}

$*, * *, * * *$ denote $10 \%, 5 \%$, and $1 \%$ significance levels, respectively. Figures in brackets represent $\mathrm{z}$-statistics.

Second, FDI in some of the OECD countries sometimes becomes a mechanism via which foreign investors take management and control over host country's firms, which might not benefit the host country due to excessive leverage or the problems of adverse selection. Krugman (1998) notes that sometimes the transfer of control occurs in a crisis and asks:

Is the transfer of control that is associated with foreign ownership appropriate under these circumstances? That is, loosely speaking, is international corporations taking over control of domestic enterprises because they have exceptional competence, and can run them better, or simply because they have cash and the locals do not? Does the fire-sale of domestic firms and their assets represent a burden to the afflicted countries, over and above the cost of the crisis itself?

Third, investment in most of the OECD countries takes a large share of the domestic market, thereby diminishing the competitiveness of local firms and leaving the emerging markets to sudden reversals of capital. Finally, some of the

104 Sciendo Studia Universitatis "Vasile Goldis" Arad. Economics Series Vol 30 Issue 4/2020 ISSN: 1584-2339; (online) ISSN: $2285-3065$

Web: publicatii.uvvg.ro/index.php/studiaeconomia. Pages $92-110$ 
Ogbeifun, L., Shobande, O.A., (2020)

Causality Analysis of Disaggregated FDI Inflows on Sectorial Growth in OECD Area

disaggregated FDI in the host country are geared towards sectors that are protected by high tariff or non-tariff barriers which strengthen lobbying efforts to preserve the prevailing misappropriation of resources.

\section{Conclusions}

The article has re-evaluated the policies and rationale for using FDI inflows to advance economic growth with a specific focus on the OECD area. Using a disaggregated approach, we investigated the link between FDI inflows and sectoral growth. We considered evaluating 25-panel dataset OECD countries for the period 1990-2013 based on the availability of data. The econometric panel techniques based on the Feasible GLS (FGLS) approach was utilized. It is considered appropriate due to possible heteroscedasticity that is likely to affect the outcome of the results. The findings show that disaggregated FDI inflows have a positive impact on economic growth. In terms of sectorial evidence, mixed evidence was reported. While we find evidence on positive and significant effects of disaggregated FDI inflows in the manufacturing and service sector, negative but insignificant effect was reported for the agricultural sector. Thus, we find no evidence to suggest that disaggregated FDI inflows promote the agricultural industry.

Further results also indicated that domestic investment and inflation has negative impacts on growth through disaggregated FDI inflows channel. This result is a warning signal that disaggregated FDI inflows crowds out domestic investment and creates inflationary pressure that is beyond a limit, if not adequately managed.

Based on the result, this study recommends that disaggregated FDI inflows can be better utilized by re-allocating them across sectors with the hope of realizing more benefits.

\section{Acknowledgements}

The authors thank the anonymous reviewers and editor for their valuable contribution.

\section{Funding}

The research received no external funding.

\section{Author Contributions}

LO conceived the study and was responsible for the data curation, methodology, formal analysis, and discussion of the results. OS was responsible for the write up of the introduction, literature reviewed, conclusion, and abstract. 
Ogbeifun, L., Shobande, O.A., (2020)

Causality Analysis of Disaggregated FDI Inflows on Sectorial Growth in OECD Area

\section{Disclosure Statement}

The authors have not any competing financial, professional, or personal interests from other parties.

\section{References}

1. Acemoglu, D., (2009), Introduction to modern economic growth, Princeton: Princeton University Press

2. Acemoglu, D., Ventura, J., (2002), The world income distribution, The Quarterly Journal of Economics, 117, pp. 659-694

3. Agiomirgianakis, G.M., Asteriou, D., Papathoma, K., (2003), The determinants of foreign direct investment: A panel data study for the OECD countries

4. Agrawal, G., Khan, M.A., (2011), Impact of FDI on GDP: A comparative study of China and India, International Journal of Business and Management, 6(10), 71

5. Alam, A., Shah, S.Z.A., (2013), Determinants of foreign direct investment in OECD member countries, Journal of Economic Studies

6. Alfaro, L., (2003)., Foreign direct investment and growth: Does the sector matter, Harvard Business School Working Paper, pp. 1-31

7. Alguacil, M., Cuadros, A., Orts, V., (2011), Inward FDI and growth: The role of macroeconomic and institutional environment, Journal of Policy Modeling, 33(3), pp. 481-496

8. Ali, H., Asgher, M., (2016), The Role of Sectoral Composition of Foreign Direct Investment on Economic Growth: A policy Proposal for CPEC and Regional Partners, The Pakistan Development Review: 89-103

9. Antras, P., Helpman, E., (2004), Global sourcing, Journal of Political Economy, 112, pp. 552-580

10. Athukorala, P., Wagle, S., (2011), Foreign Direct Investment in Southeast Asia: Is Malaysia falling behind

11. Ayyagari, M., Kosová, R., (2010), Does FDI facilitate domestic entry? Evidence from the Czech Republic, Review of International Economics, 18(1), pp. 14-29

12. Balakrishnan, M.S., Muhammad, N., Sikdar, A., Rogmans, T., Ebbers, H. (2013). The determinants of foreign direct investment in the Middle East North Africa region, International Journal of Emerging Markets

13. Balasubramanyam, V.N., Salisu, M., Sapsford, D., (1999), Foreign direct investment as an engine of growth, Journal of International Trade \& Economic Development, 8(1), pp. 27-40

14. Bano, S., Tabbada, J., (2015), Foreign Direct Investment Outflows: Asian Developing Countries, Journal Economic Integration; 30(2), pp. 359-398

106 Sciendo Studia Universitatis "Vasile Goldis" Arad. Economics Series Vol 30 Issue 4/2020 ISSN: 1584-2339; (online) ISSN: $2285-3065$

Web: publicatii.uvvg.ro/index.php/studiaeconomia. Pages $92-110$ 
Ogbeifun, L., Shobande, O.A., (2020)

Causality Analysis of Disaggregated FDI Inflows on Sectorial Growth in OECD Area

15. Bengoa, M., Sanchez-Robles, B., (2003), Foreign direct investment, economic freedom and growth: new evidence from Latin America, European journal of political economy, 19(3), pp. 529-545

16. Bissinger, J., (2012), Foreign Investment in Myanmar: A resource boom but a development bust?, Contemporary South East Asia; 34(1), pp. 23-52

17. Blonigen, B.A., Piger, J., (2014), Determinants of Foreign Direct Investment, The Canadian Journal of Economics, 47(3), pp. 775-812

18. Buchanan, B.G., Le, Q.V., Rishi, M., (2012), Foreign direct investment and institutional quality: Some empirical evidence, International Review of financial analysis, 21, pp. 81-89

19. Campos, N.F., Kinoshita, Y., (2002), Foreign direct investment as technology transferred: Some panel evidence from the transition economies, The Manchester School, 70(3), pp. 398-419

20. Chen, (2015), The impact of Coastal FDI on Inland Economic Growth in China, In the book title: China Transformation in a Global Context, Anu Press

21. Chakraborty, C., Nunnenkamp, P., (2008), Economic reforms, FDI, and economic growth in India: a sector level analysis, World development, 36(7), pp. 1192-1212

22. Danzman, S.B., (2020), Foreign direct investment policy, domestic firms, and financial constraints, Business and Politics, 22(2), pp. 279-306

23. De Mello, L.R., (1997), Foreign Direct Investments in Developing Countries and Growth: A Selective Survey, Journal of Development Studies, 34(1997), pp. 115-35

24. De Mello, L.R., (1999), Foreign direct investment-led growth: evidence from time series and panel data, Oxford Economic Papers, 51(1), pp. 133-151

25. Galego, A., Vieira, C., Vieira, I., (2004), The CEECs as FDI Attractors: A Menace to the EU Periphery, Emerging Markets Finance \& Trade, 40(5): 7

26. Ghosh, M., Wang, W., (2010), Does FDI Accelerate Economic Growth? The OECD Experience Based on Panel Data Estimates for the Period 19802004, Global Economy Journal, 9(4)

27. Ghosh, M., Syntetos, P., Wang, W., (2012), Impact of FDI restrictions on inward FDI in OECD countries, Global Economy Journal, 12(3), pp. 185-265

28. Golub, S.S., (2003), Measures of restrictions on inward foreign direct investment for OECD countries

29. Hausmann, R., Fernandez-Arias, E., (2000), Foreign direct investment: good cholesterol?

30. Hayakawa, K., Kimura, F., Lee, H.H., (2013), How does country risk matter for foreign direct investment?, The Developing Economies, 51(1), pp. 60-78 
Ogbeifun, L., Shobande, O.A., (2020)

Causality Analysis of Disaggregated FDI Inflows on Sectorial Growth in OECD Area

31. Hoang, T., Wiboonchutikula, P., Tubtimtong, B., (2010), Does Foreign Direct Investment Promote Economic Growth in Vietnam?, ASEAN Economic Bulletin; 27, pp. 295-311

32. Hsiao, C., Shen, Y., (2003), Foreign direct investment and economic growth: the importance of institutions and urbanization, Economic development and Cultural change, 51(4), pp. 883-896

33. Hunya, G., (2002), Recent impacts of foreign direct investment on growth and restructuring in Central European transition countries (No. 284), WIIW Research Report

34. Iwasaki, I., Tokunaga, M., (2014), Macroeconomic impact of FDI in transition economies: A Meta-Analysis, World Development; 61, pp. 53-69

35. Kapuria-Foreman, V., (2007), Economic freedom and foreign direct investment in developing countries, The Journal of Developing Areas, pp. 143-154

36. Koyama, T., Golub, S.S., (2006), OECD's FDI regulatory restrictiveness index: revision and extension to more economies

37. Kurtishi-Kastrati, S., (2013), The effects of foreign direct investments for host country's economy, European Journal of Interdisciplinary Studies, 5(1), 26

38. Krugman, P., (2000), Fire-sale FDI, In Capital flows and the emerging economies: theory, evidence, and controversies (pp. 43-58), University of Chicago Press

39. Leibrecht, M., Scharler, J., (2009), How Important is Employment Protection Legislation for Foreign Direct Investment Flows in Central and Eastern European Countries? http://dx.doi.org/10.1111/j.1468-0351.2009.00353.x

40. Lenaerts, K., Merlevede, B., (2015), Firm size and spillover effects from Foreign Direct Investment: The case of Romania, Small Business Economics, 45, pp. 595-611

41. Lim, D., (1983), Fiscal Incentive and Direct Foreign Investment in Less Developed Countries, Journal of Development Studies, 19(2), pp. 207-212

42. Madariaga, N., Poncet, S., (2007), FDI in Chinese cities: Spillovers and impact on growth, World Economy, 30(5), pp. 837-862

43. Mahembe, E., Odhiambo, N.M., (2014), A critical review of FDI inflows and economic growth in low-income SADC countries: prospects and challenges, Problems and perspectives in management, (12, Iss. 1), pp. 7-16

44. Masron, T.A., Shahbudin, A.S., (2010), Push factors of outward FDI: Evidence from Malaysia and Thailand, Journal of Business \& Policy Research, 5, pp. 54-68 45. Mukhopadhyay, K., (2006), Impact on the Environment of Thailand's Trade with OECD Countries, Asia-Pacific Trade and Investment Review, 2(1), pp. 25-46 46. Nasir, M.A., Ahmed, F., Ahmed, M., (2016), Foreign Direct Investment, Aggregate Demand conditional, and exchange Nexus: A panel data analysis of BRICS economies, Global economy

108 Sciendo Studia Universitatis "Vasile Goldis" Arad. Economics Series Vol 30 Issue 4/2020 ISSN: 1584-2339; (online) ISSN: $2285-3065$

Web: publicatii.uvvg.ro/index.php/studiaeconomia. Pages $92-110$ 
Ogbeifun, L., Shobande, O.A., (2020)

Causality Analysis of Disaggregated FDI Inflows on Sectorial Growth in OECD Area

47. Nicoletti, G., Scarpetta, S., (2006), Regulation and economic performance: product market reforms and productivity in the OECD, Institutions, Development, and Economic Growth, 13, 81

48. OECD. Publishing, (2019), OECD International Direct Investment Statistics 2019, OECD Publishing

49. Ouyang, P., Fu, S., (2012), Economic growth, industrial development and the inter-regional spillovers from foreign direct investment: Evidence of China, China Economic Review, 23(2), pp. 445-60

50. Ozkan-Gunay, N., (2011), Determinants of FDI inflows and policy implications: A comparative study for the enlarged EU and Candidate Countries, Emerging Markets Finance \& Trade; 47(4), pp. 71-85

51. Pazienza, P., (2015), The environmental impact of the FDI inflow in the transport sector of OECD countries and policy implications, International Advances in Economic Research, 21(1), pp. 105-116

52. Ray, E.J., (1989), The Determinants of Foreign Direct Investment in the United States, 1979-85, in Robert C. Feenstra, ed., Trade Policies for International Competitiveness, pp. 53-84, University of Chicago Press

53. Rios-Morales, R., Brennan, L., Schweizer, M., (2016), An Assessment of Chinese Foreign Direct Investment in Switzerland, International Relations, 13(49), pp. 85-105

54. Rjoub, H., Aga, M., Abu Alrub, A., Bein, M., (2017), Financial reforms and determinants of FDI: evidence from landlocked countries in Sub-Saharan Africa, Economies, 5(1), 1

55. Ruane, F., Görg, H., (1997), The impact of foreign direct investment on sectoral adjustment in the Irish economy, National Institute Economic Review, 160(1), pp. 76-86

56. Sadik, A.T., Bolbol, A.A., (2001), Capital flows FDI and technology spillovers: Evidence from Arab countries, World Development, 29, pp. 2111-2125

57. Sohinger, J., (2005), Growth and convergence in European transition economies: The impact of foreign direct investment, Eastern European Economics, 43(2), pp. 73-94

58. Solow, R., (1956), A Contribution to the Theory of Economic Growth, The Quarterly Journal of Economics, 70 (1), pp. 65-94

59. Tsai, P., (1994), Determinants of Foreign Direct Investments and its Impact on Economic Growth, Journal of Economic Development, 19, pp. 137-163

60. Turkcan, B., Yetkiner, I.H., (2010), Endogenous determination of FDI growth and economic growth: the OECD case, International Journal of Public Policy, 5(4), pp. $409-429$ 
Ogbeifun, L., Shobande, O.A., (2020)

Causality Analysis of Disaggregated FDI Inflows on Sectorial Growth in OECD Area

61. Vu, T.B., Noy, I., (2009), Sectoral analysis of foreign direct investment and growth in the developed countries, Journal of International Financial Markets, Institutions and Money, 19(2), pp. 402-413

62. Wang, L., Meijers, H., Szirmai, A., (2017), Technological spillovers and industrial growth in Chinese regions, Industrial and Corporate Change, 26(2), pp. 233-257

63. Wang, C., Balasubramanyam, V.N., (2011), Aid and foreign direct investment in Vietnam, Journal of Economic Integration, pp. 721-739

64. Wiggins, V., Poi, B., (2001), Testing for panel-level heteroskedasticity and autocorrelation, [Online] http://www.stata.com/support/faqs/statistics/panel-levelheteroskedasticityand-autocorrelation/ (Accessed March 20, 2015)

65. Wooster, R., Diebel, D., (2010), Productivity Spillover from Foreign Direct Investment in Developing Countries: A Meta Regressiob Analysis, Review of Development, 14(3), pp. 640-655

66. Yi, J., Chen, Y., Wang, C., Kafouros, M., (2015), Spillover effects of foreign direct investment: how do region-specific institutions matter?, Management International Review, 55(4), pp. 539-561

67. Zang, W., Baimbridge, M.J., (2014), Foreign Direct Investment and economic growth in OECD countries

68. Zekarias, S.M., (2016), The impact of foreign direct investment (FDI) on economic growth in Eastern Africa: Evidence from panel data analysis, Applied Economics and Finance, 3(1), pp. 145-160

69. Zhang, Z., (2002), Productivity and economic growth: an empirical assessment of the contribution of FDI to the Chinese economy, Journal of Economic Development, 27(2), pp. 81-94 